\title{
Investigating molecular basis of lambda- cyhalothrin resistance in an Anopheles funestus population from Senegal
}

\author{
Badara Samb $^{1 *}$, Lassana Konate ${ }^{1}$, Helen Irving ${ }^{2}$, Jacob M. Riveron ${ }^{2,3}$, Ibrahima Dia ${ }^{4}$, Ousmane Faye ${ }^{1}$
} and Charles S. Wondji $\mathrm{j}^{2,3}$

\begin{abstract}
Background: Anopheles funestus is one of the major malaria vectors in tropical Africa, notably in Senegal. The highly anthropophilic and endophilic behaviours of this mosquito make it a good target for vector control operations through the use of insecticide treated nets, long-lasting insecticide nets and indoor residual spraying. However, little is known about patterns of resistance to insecticides and the underlying resistance mechanisms in field populations of this vector in Senegal.
\end{abstract}

Methods: Here, we assessed the susceptibility status of An. funestus populations from Gankette Balla, located in northern Senegal and investigated the potential resistance mechanisms.

Results: WHO bioassays indicated that An. funestus is resistant to lambda-cyhalothrin $0.05 \%$ (74.64 \% mortality), DDT $4 \%$ (83.36 \% mortality) and deltamethrin $0.05 \%$ (88.53 \% mortality). Suspected resistance was observed to permethrin $0.75 \%$ (91.19 \% mortality), bendiocarb $0.1 \%$ (94.13\% mortality) and dieldrin $4 \%$ (96.41 \% mortality). However, this population is fully susceptible to malathion $5 \%$ (100\% mortality) and fenitrothion $1 \%$ (100\% mortality). The microarray and qRT-PCR analysis indicated that the lambda-cyhalothrin resistance in Gankette Balla is conferred by metabolic resistance mechanisms under the probable control of cytochrome P450 genes among which CYP6M7 is the most overexpressed. The absence of overexpression of the P450 gene, CYP6P9a, indicates that the resistance mechanism in Senegal is different to that observed in southern Africa.

Conclusions: This study represents the first report of pyrethroid and DDT resistance in An. funestus from Senegal and shows that resistance to insecticides is not only confined to An. gambiae as previously thought. Therefore, urgent action should be taken to manage the resistance in this species to ensure the continued effectiveness of malaria control.

Keywords: Anopheles funestus, Insecticide resistance, Lambda-cyhalothrin, Resistance mechanisms, Senegal

\section{Background}

The burden of malaria remains heaviest in the WHO African region, where an estimated $90 \%$ of all malaria deaths occur, and in children aged under five years, who account for $78 \%$ of all deaths [1]. In Senegal, malaria is a major cause of morbidity and mortality and a high priority for the government, even though the number of

\footnotetext{
* Correspondence: badarasb@gmail.com

'Laboratoire d'Écologie Vectorielle et Parasitaire, Département de Biologie Animale, Faculté des Sciences et Techniques, Université Cheikh Anta Diop de Dakar, Dakar-Fann, BP 5005, Sénégal

Full list of author information is available at the end of the article
}

reported cases of malaria has dropped significantly since 2007-2008 [2]. As in many African countries, malaria control in Senegal relies heavily on vector control through the use of long-lasting insecticide nets (LLINs) and indoor residual spraying (IRS). However, resistance to the main insecticides in the major malaria vectors such as Anopheles funestus is threatening the success of these control interventions. Resistance to different classes of insecticides used in public health is increasingly reported across Africa in An. funestus with fear that this could disrupt control programs against this vector. Indeed, resistance to pyrethroids, DDT and carbamates 
has been reported in different regions of Africa including southern Africa [3-6], Central Africa [7], East Africa $[8,9]$ and West Africa [10, 11]. In Senegal, pyrethroid resistance until recently was mainly reported in $A n$. gambiae [12-14] while little is known about the susceptibility of An. funestus to insecticides. Senegal is currently scaling up its malaria control program through LLINs and IRS $[15,16]$. It is crucial that information on susceptibility to main insecticides used in public health and the underlying mechanisms be investigated. This will properly inform control programs of the most suitable insecticides to use and facilitate the design of appropriate resistance management strategies. In this study, we report the assessment of the susceptibility of one An. funestus population from northern Senegal to several insecticides used in public health and also investigate the underlying molecular mechanisms conferring resistance to lambdacyhalothrin, a key pyrethroid insecticide used for IRS. This information will fill the gap in our knowledge on the resistance distribution in $A n$. funestus and help to improve future control programs on this species in Senegal.

\section{Methods}

\section{Study site and mosquito collection}

Blood-fed An. funestus adult females resting indoor were collected in houses between 7.00 am and $15.00 \mathrm{pm}$ in November 2011, in Gankette Balla $\left(15^{\circ} 58^{\prime} \mathrm{N}, 15^{\circ} 55^{\prime} \mathrm{W}\right)$, which is located in the Lake Guiers area, in northern Senegal, West Africa. Blood-fed and gravid mosquitoes resting inside houses were collected using aspirators and torches and kept in small cups, covered by a non-treated net, until fully gravid and transported to the insectary where they were allowed to lay eggs [17] and hatch in larvae bowls for rearing. The egg batches were pooled and reared together and the $F_{1}$ adults generated were randomly mixed in cages for subsequent experiments.

\section{Species identification}

All females used for individual oviposition were morphologically identified as belonging to the An. funestus group [18]. Genomic DNA was extracted from head and thorax using the Livak protocol as previously described [19]. A cocktail PCR was carried to confirm that all females that laid eggs were An. funestus (s.s.) [20].

\section{Adult mosquito susceptibility assays}

Insecticide susceptibility assays were carried out using 2-5 day-old $F_{1}$ adults following the WHO protocol [21]. Approximately 20-25 mosquitoes per tube with 4-6 replicates were exposed to insecticide-impregnated filter paper for $1 \mathrm{~h}$ or control paper and then transferred to a clean holding tube supplied with $10 \%$ sugar and mortality was determined $24 \mathrm{~h}$ post-exposure. We tested the following insecticides: the pyrethroids permethrin
(0.75\%), lambda-cyhalothrin (0.05\%) and deltamethrin $(0.05 \%)$; the carbamate bendiocarb $(0.01 \%)$; the organophosphate malathion (5\%) and fenitrothion (5\%) and the organochlorines DDT (4\%) and dieldrin (4\%).

\section{Microarray analysis}

A custom microarray chip [3] containing $8 \times 60 \mathrm{k}$ probes (60mer) (A-MEXP-2374) was used to identify the set of genes associated with lambda-cyhalothrin resistance [22]. RNA was extracted from three batches of $10 \mathrm{An}$. funestus females that were 2-5 day-old from the following sample sets: alive after exposure to $0.75 \%$ lambdacyhalothrin (R); unexposed to insecticides and thus representative of the wild-type population (C); and unexposed mosquitoes from the fully susceptible laboratory strain FANG (S). RNA was isolated using the Picopure RNA isolation kit (Arcturus, Applied Biosystems, Carlsbad, CA, USA). The quantity and quality of extracted RNA were assessed using a NanoDrop ND1000 spectrophotometer (Thermo Fisher Scientific, Waltham, MA, USA) and a Bioanalyzer (Agilent, Santa Clara, CA, USA), respectively. cRNA of each sample was amplified using the Agilent Quick Amp labeling kit (two-colour) following the manufacturer's protocol. cRNA from the resistant samples (R) were labelled with cy5 dye and cRNA from the control (C) were labelled with both cy3 and cy5, whereas the susceptible strain FANG (S) was labelled with the cy3 dye. cRNA quantity and quality were checked after labelling using the NanoDrop spectrophotometer and Bioanalyzer. Labelled cRNAs were hybridized to the arrays for $17 \mathrm{~h}$ at $65{ }^{\circ} \mathrm{C}$ according to the manufacturer's protocol. Five hybridizations for each of the comparisons (R-S, R-C and C-S) were carried out by swapping the biological replicates. Microarray data were analysed using Genespring GX 12.0 software. To identify differentially expressed genes, a cut-off of 1.5 (R-C) and 2-fold-change (FC) (R-S and C-S) and a statistical significance of $\mathrm{P} \leq 0.05$ with Benjamin-Hochberg correction for multiple testing were applied.

\section{Transcription profiling of candidate metabolic resistance genes (qRT-PCR)}

The main candidates resistance genes (Additional file 1: Table S1) that were highly overexpressed from the microarray analysis were assessed by quantitative Reverse Transcriptase PCR (qRT-PCR) to validate their expression pattern using three biological replicates ( 10 females $F_{1}$ for each replicate) for lambda-cyhalothrin resistant mosquitoes (R) (alive after $24 \mathrm{~h}$ exposure to lambda-cyhalothrin), control mosquitoes (C) (not exposed to any insecticide) and susceptible FANG mosquitoes (S). One microgram of total RNA from each of the three biological replicates for resistant (R), control (C), and FANG (S) was used as a template for cDNA synthesis using the Super-Script III 
(Invitrogen, Carlsbad, CA, USA) with oligo-dT20 and RNase $\mathrm{H}$, according to the manufacturer's instructions. A serial dilution of cDNA was used to establish standard curves for each gene to assess PCR efficiency and quantitative differences between samples. The q-RTPCR amplification was carried out in a MX3005 realtime PCR system (Agilent, Santa Clara, CA, USA) using Brilliant III Ultra-Fast SYBR Green QPCR Master Mix (Agilent). A total of $10 \mathrm{ng}$ of cDNA from each sample was used as template in a three-step program involving a denaturation at $95^{\circ} \mathrm{C}$ for $3 \mathrm{~min}$ followed by 40 cycles of $10 \mathrm{~s}$ at $95{ }^{\circ} \mathrm{C}$ and $10 \mathrm{~s}$ at $60{ }^{\circ} \mathrm{C}$ and a last step of $1 \mathrm{~min}$ at $95{ }^{\circ} \mathrm{C}, 30 \mathrm{~s}$ at $55^{\circ} \mathrm{C}$, and $30 \mathrm{~s}$ at $95^{\circ} \mathrm{C}$. The relative expression and fold-change of each target gene in $\mathrm{R}$ and $\mathrm{C}$ relative to $\mathrm{S}$ was calculated according to the $2^{-\Delta \Delta C T}$ method incorporating PCR efficiency [23] after normalization with the housekeeping RSP7 (ribosomal protein S7; AFUN007153-RA) and the Actin (AFUN006819) genes.

\section{Investigation of the role of knockdown resistance mutation in lambda-cyhalothrin resistance}

A fragment spanning a portion of the voltage-gated sodium channel gene (VGSC), including the 1014 codon associated with resistance in An. gambiae, was amplified using the KdrFunF2/KdrFunR2 primers [9, 11, 24] and sequenced (KdrFunR2) in ten field-collected $A n$. funestus female mosquitoes from Gankette Balla. PCR, sequencing and analysis were carried out as previously described $[9,11,24]$.

\section{Results}

\section{Mosquito collection}

More than 450 blood-fed An. funestus females were collected inside houses in the village of Gankette Balla over a period of four days in November 2011. Around 150 laid eggs and all were confirmed to be An. funestus (s.s.) by PCR.

\section{Insecticide susceptibility}

A total of 2,322 $\mathrm{F}_{1}$ An. funestus adults from Gankette Balla were generated and exposed to various insecticides (Additional file 2: Table S2). The bioassay performed indicated that the An. funestus population females were resistant to the type II pyrethroids lambda-cyhalothrin and deltamethrin as well as to the organochlorine DDT with mortality rates of $74.64 \%$, $88.53 \%$ and $83.36 \%$, respectively. Suspected resistance was observed to permethrin, bendiocarb and dieldrin with mortality rates of $91.19 \%, 94.13 \%$ and $96.41 \%$, respectively. However, this population was fully susceptible to the organophosphates malathion and fenitrothion with a mortality rate of $100 \%$. The males of this $A n$. funestus population were generally susceptible to exposed insecticides except for DDT and lambda-cyhalothrin for which a moderate resistance was observed with mortality rates of $90.30 \%$ and $97.30 \%$, respectively (Fig. 1).

\section{Genome-wide microarray-based transcription analysis of lambda-cyhalothrin resistance}

The total number of differentially expressed probes for the comparison between lambda-cyhalothrin resistant samples and the susceptible strain FANG (R-S) was 7,897 (3,789 overexpressed); 7,768 (4,055 overexpressed) for the comparison between the control wild type samples $(\mathrm{C})$ and the susceptible strain FANG (C-S); 115 (59 overexpressed) for the comparison between lambdacyhalothrin resistant samples and the control wild type samples R-C) (Fig. 2). Fourteen probes were commonly differentially expressed in the three types of comparison (R-S, C-S and R-C). However, 5,388 probes were commonly differentially expressed in the R-S and C-S comparisons, whereas 44 and 18 probes were respectively commonly differentially expressed in the pairs of comparisons R-S vs R-C and C-S vs R-C (Fig. 2).

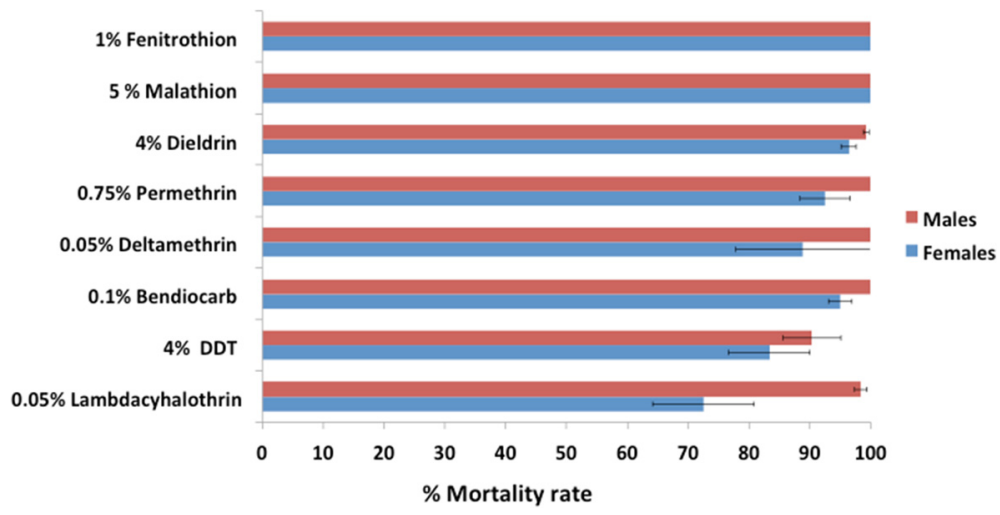

Fig. 1 Insecticide resistance profile of Anopheles funestus populations from Gankette Balla 


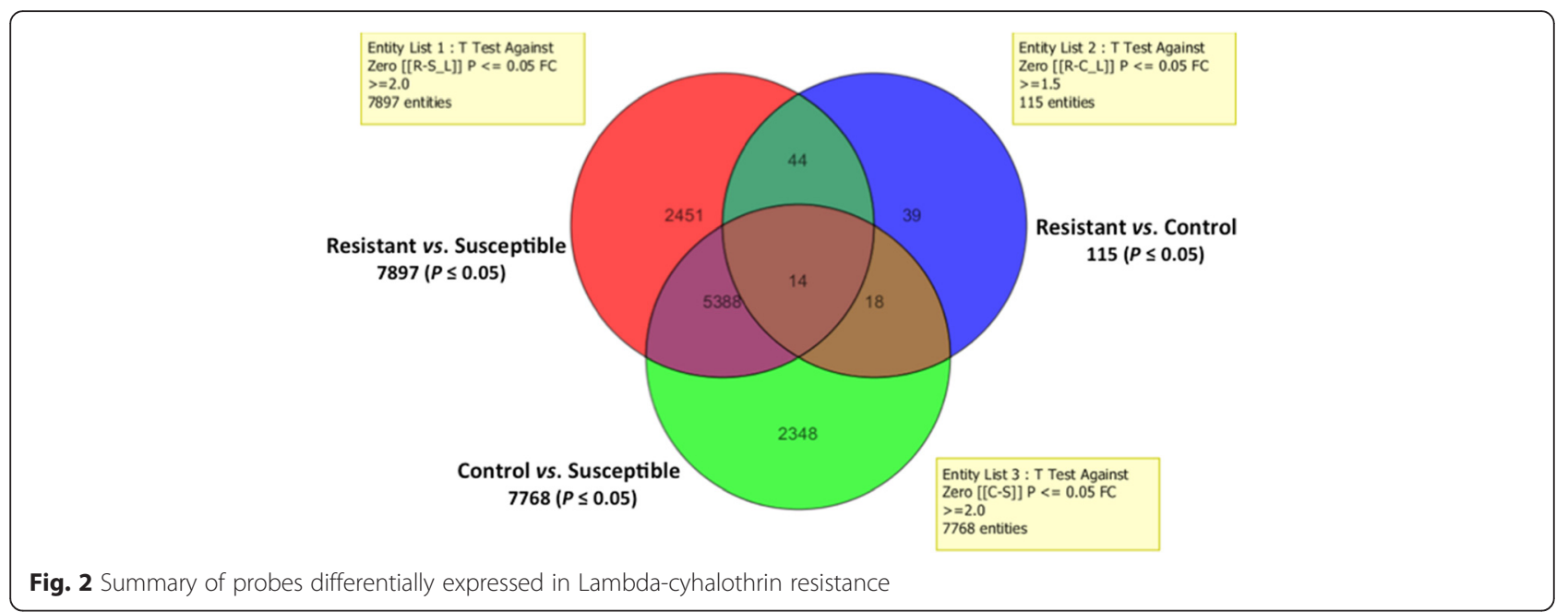

\section{Genes commonly overexpressed in R-S, C-S and R-C comparisons}

A probe for the CYP6M7 transcript, belonging to the cytochrome P450 gene family, was the most commonly overexpressed detoxification gene in the R-S (FC 101.64) and C-S (FC 120.09) comparisons. This gene was also significantly overexpressed in the $\mathrm{R}-\mathrm{C}$ comparison but with a much lower FC value (2.59) (Table 1). Other cytochrome P450s genes that were also commonly overexpressed in the three comparisons were three other $\mathrm{P} 450$ genes including CYP6AH1 (combined_c1486), CYP304b1 and CYP4C36 (Afun007127). The transcripts Afun008293 and Afun009227 belonging to trypsin-related protease and argininosuccinate lyase genes respectively, were commonly highly overexpressed in R-S and C-S comparisons and significantly overexpressed in R-C. Transcripts belonging to others detoxification genes family such as glutathione transferase (GSTd3), abc transporter (Afun015523), carboxylesterase (Afun011942) were also significantly commonly overexpressed in the three comparisons (Table 1).

\section{Genes commonly overexpressed in R-S and C-S comparisons}

Several detoxification genes or resistance-related genes were commonly and significantly overexpressed in the R-S and C-S comparison. A set of five transcripts belonging to cytochrome P450s genes was commonly upregulated in R-S and C-S, with CYP4H25 (FC 10.60; 4.99), CYP4C27 (FC9.98; 21.93) and CYP4H17 (FC9.82; 4.86) being the most overexpressed (Table 1). A transcript (Afun007369) with closest hit to CYP6P9b (92 \%) was also overexpressed in both R-S (FC4.04) and C-S (FC4.68). However, none of the three probes designed for CYP6P9a was overexpressed in this population, suggesting a significant difference with southern African populations where this P450 is highly overexpressed. Among the most commonly overexpressed resistance-associated genes in R-S and C-S were the high affinity GABA transporter (Afun009312) and an ankyrin repeat domain protein (Afun005545). Noticeably, the transcripts Afun008698 and AGAP000177-RA belonging to heat shock protein $70 \mathrm{~b} 2$ and cuticle protein 7 genes successively were commonly overexpressed with a high FC observed in C-S. Furthermore, several probes from the GSTs gene family were also significantly and commonly overexpressed in R-S and C-S in possible association with the observed DDT resistance in this population. These GST genes include the GSTd1-5 previously also reported in southern African populations of An. funestus [4]. However, GSTe2, the major DDT resistance gene observed in West and Central African countries [4] is overexpressed in this Senegalese population. The other detoxification or resistance related genes are reported in Table 1 and Additional file 3: Table S3 and include short-chain dehydrogenase, esterase b1, aldehyde oxidase and chymotrypsin 1.

\section{Genes commonly overexpressed in R-C and R-S comparisons} Only a limited number of genes were commonly overexpressed in the two comparisons. Indeed, these genes include: a single P450 (CYP9J5), three probes corresponding to An. gambiae orthologous genes, one probe for membrane-associated LPS-inducible TNF-alpha factor protein and zinc metalloproteinase nas-12, successively (Table 1). The top 50 of the most detoxification genes overexpressed only in the comparisons R-S_L (Mosquitoes resistant to lambda-cyhalothrin $v s$ susceptible mosquitoes) and R-C_L (Mosquitoes resistant to lambda-cyhalothrin $v s$ control mosquitoes) are presented in Additional file 4: Tables S4 and Additional file 5: Table S5, respectively. 
Table 1 Transcripts from detoxification genes with lambda-cyhalothrin resistance upregulated in various comparisons (R-C, R-S and (-S) in Gankette Balla

\begin{tabular}{|c|c|c|c|c|c|}
\hline Probe name & Transcript & $\mathrm{R}-\mathrm{C}$ & R-S & C-S & Description \\
\hline CUST_7663_PI426302897 & CYP6M7 & 2.59 & 101.64 & 120.09 & cytochrome p450 \\
\hline CUST_2949_PI406199769 & combined_c1486 (CYP6AH1) & 1.52 & 5.59 & 5.27 & cytochrome p450 \\
\hline CUST_12197_PI426302897 & CYP304b1 & 1.61 & 4.44 & 2.74 & cytochrome p450 \\
\hline CUST_7127_PI426302897 & Afun007127 (CYP4C36) & 2.17 & 3.23 & 2.90 & cytochrome p450 \\
\hline CUST_8293_PI426302897 & Afun008293 & 1.78 & 79.77 & 63.27 & trypsin-related protease \\
\hline CUST_13921_PI426302897 & Afun013921 & 2.21 & 34.28 & 25.55 & chymotrypsin 1 \\
\hline CUST_8354_PI426302897 & GSTD3 & 1.52 & 6.33 & 4.69 & glutathione transferase (agap004382-pa) \\
\hline CUST_7773_PI426302897 & Afun007773 & 1.57 & 6.06 & 4.00 & microsomal glutathione s-transferase \\
\hline CUST_9227_PI426302897 & Afun009227 & 1.79 & 29.78 & 42.82 & argininosuccinate lyase \\
\hline CUST_15523_PI426302897 & Afun015523 & 1.55 & 8.39 & 8.34 & abc transporter \\
\hline CUST_14150_PI426302897 & Afun014150 & 1.64 & 7.51 & 4.70 & oxidative stress-induced growth \\
\hline CUST_11942_PI426302897 & Afun011942 & 1.63 & 3.47 & 3.20 & carboxylesterase \\
\hline CUST_376_PI406199788 & gb-CYP4H25 & & 10.60 & 4.99 & cytochrome p450 \\
\hline CUST_12777_PI426302897 & CYP4C27 & & 9.98 & 21.93 & cytochrome p450 \\
\hline CUST_4223_PI426302897 & CYP4H17 & & 9.82 & 4.86 & cytochrome p450 \\
\hline CUST_12343_PI426302897 & CYP4H17 & & 6.46 & 3.90 & cytochrome p450 \\
\hline CUST_12197_PI426302897 & Afun012197 (CYP304B1) & & 4.44 & 2.74 & cytochrome p450 \\
\hline CUST_7369_PI426302897 & Afun007369 (CYP6P9b) & & 4.04 & 4.68 & cytochrome p450 \\
\hline CUST_9312_PI426302897 & Afun009312 & & 25.95 & 38.54 & high affinity gaba transporter \\
\hline CUST_3489_PI406199769 & combined_c1762 & & 4.48 & 3.52 & abc transporter \\
\hline CUST_5545_PI426302897 & Afun005545 & & 14.97 & 18.72 & ankyrin repeat domain protein \\
\hline CUST_3386_PI426302897 & Afun003386 & & 5.50 & 4.54 & ankyrin repeat domain-containing protein 50 \\
\hline CUST_10406_PI426302897 & Afun010406 & & 4.15 & 3.86 & ankyrin repeat domain-containing protein 50 \\
\hline CUST_1930_PI426302897 & Afun001930 & & 4.39 & 3.88 & ankyrin repeat-containing \\
\hline CUST_3672_PI426302897 & Afun003672 & & 4.35 & 4.19 & multiple ankyrin repeats single kh d. protein \\
\hline CUST_1459_PI406199769 & combined_c738 & & 9.17 & 10.93 & short-chain dehydrogenase \\
\hline CUST_2520_PI406199772 & CD578141.1 & & 5.54 & 6.72 & short-chain dehydrogenase \\
\hline CUST_10105_PI426302897 & Afun010105 & & 3.38 & 2.44 & short-chain dehydrogenase \\
\hline CUST_12461_PI426302897 & Afun012461 & & 8.67 & 3.72 & alcohol dehydrogenase \\
\hline CUST_665_PI406199788 & gb-NADH_dehyd & & 2.86 & 4.87 & nadh dehydrogenase \\
\hline CUST_10836_PI426302897 & Esterase b1 & & 7.33 & 3.75 & esterase b1 \\
\hline CUST_11942_PI426302897 & Afun011942 & & 3.47 & 3.20 & carboxylesterase \\
\hline CUST_34_PI406199775 & COEAE6O & & 2.41 & 2.05 & carboxylesterase \\
\hline CUST_13332_PI406199769 & combined_c6826 & & 2.06 & 2.33 & esterase b1 \\
\hline CUST_295_PI406199798 & AGAP000177-RA & & 7.06 & 16.73 & cuticle protein 7 \\
\hline CUST_3736_PI406199772 & CD577515.1 & & 5.94 & 3.38 & cuticle protein \\
\hline CUST_8354_PI426302897 & GSTD3 & & 6.33 & 4.69 & glutathione transferase (agap004382-pa) \\
\hline CUST_7773_PI426302897 & Afun007773 & & 6.06 & 4.00 & microsomal glutathione s-transferase \\
\hline CUST_1870_PI406199769 & combined_c944 & & 4.25 & 2.09 & microsomal glutathione s-transferase \\
\hline CUST_10360_PI426302897 & Afun010360 & & 2.63 & 2.84 & glucosyl glucuronosyl transferases \\
\hline CUST_7499_PI426302897 & GSTd1-5 & & 2.55 & 2.48 & glutathione transferase \\
\hline CUST_8698_PI426302897 & Afun008698 & & 5.74 & 25.76 & heat shock protein 70 b2 \\
\hline
\end{tabular}


Table 1 Transcripts from detoxification genes with lambda-cyhalothrin resistance upregulated in various comparisons (R-C, R-S and (-S) in Gankette Balla (Continued)

\begin{tabular}{|c|c|c|c|c|c|}
\hline CUST_7498_PI426302897 & Afun007498 & & 3.69 & 2.81 & heat shock cognate 70 protein \\
\hline CUST_7302_PI426302897 & Afun007302 & & 3.34 & 3.86 & heat shock $70 \mathrm{kda}$ protein cognate 4 \\
\hline CUST_5336_PI426302897 & Afun005336 & & 2.94 & 4.69 & heat shock cognate $70 \mathrm{kda}$ protein \\
\hline CUST_2701_PI406199769 & combined_c1362 & & 2.77 & 2.35 & heat shock protein 70 -interacting protein \\
\hline CUST_2184_PI406199772 & CD578312.1 & & 2.30 & 3.18 & 82 kda heat shock protein \\
\hline CUST_3246_PI426302897 & Afun003246 & & 5.12 & 5.83 & aldehyde oxidase \\
\hline CUST_11963_PI426302897 & Afun011963 & & 4.56 & 4.55 & aldehyde oxidase \\
\hline CUST_718_PI406199788 & $g b-P X 4 B$ & & 4.32 & 4.43 & oxidase peroxidase \\
\hline CUST_199_PI426302897 & Afun000199 & & 3.04 & 3.46 & chorion peroxidase \\
\hline CUST_7400_PI426302897 & Afun007400 & & 2.57 & 3.12 & thioredoxin-dependent peroxidase \\
\hline CUST_8347_PI426302897 & Afun008347 & & 5.07 & 3.21 & chymotrypsin 1 \\
\hline CUST_11697_PI426302897 & Afun011697 & & 3.04 & 4.34 & chymotrypsin bii \\
\hline CUST_7894_PI426302897 & Afun007894 & & 5.50 & 4.34 & trypsin delta gamma \\
\hline CUST_1313_PI426302897 & Afun001313 (CYP9J5) & 2.93 & 2.67 & & cytochrome p450 \\
\hline CUST_11293_PI426302897 & Afun011293 & 4.22 & 4.97 & & AGAP012443-PA [Anopheles gambiae str. PEST] \\
\hline CUST_4992_PI426302897 & Afun004992 & 3.46 & 2.61 & & AGAP010545-PA [Anopheles gambiae str. PEST] \\
\hline CUST_9542_PI426302897 & Afun009542 & 2.32 & 2.58 & & AGAP000321-PA [Anopheles gambiae str. PEST] \\
\hline CUST_9600_PI406199769 & combined_c4862 & 1.51 & & 2.53 & ankyrin unc44 \\
\hline
\end{tabular}

Abbreviations: R-C Resistant-Control, R-S Resistant-Susceptible, C-S Control-Susceptible

Genes commonly overexpressed in R-C and C-S comparisons Only one transcript (combined_c4862) belonging to ankyrin unc44 gene was commonly overexpressed in $\mathrm{R}-\mathrm{C}$ (FC 1.51) and C-S (FC 2.53) comparisons (Table 1).

\section{Genes commonly underexpressed in lambda-cyhalothrin resistant mosquitoes}

The detoxifying gene "CD578215.1" (cuticle protein) was the most commonly underexpressed gene in the R-S_L (FC 24.47), C-S (FC 56.22) and R-C_L (FC 1.52) comparisons. Other genes that were commonly underexpressed in these three comparisons include: combined_c3712 (stresssensitive b), CD577548.1 (cytochrome $c$ oxidase subunit 1), CD577574.1 (glutathione s-transferase) (Additional file 6: Table S6). The detoxifying gene "Afun013280" (carboxypeptidase $\mathrm{n}$ subunit 2) was the most commonly under expressed gene in the R-S_L (FC 29.52) and C-S (FC 16.58) comparisons. Among the others detoxifying gene families commonly underexpressed in R-S_L and CS, we noted the presence of many probes from cytochrome $c$ oxidase subunit III and also from F0 ATP synthase subunit 6 (Additional file 7: Table S7). The top 50 of the most detoxification genes underexpressed only in the comparisons R-S_L and R-C_L are presented in Additional file 8: Table S8 and Additional file 9: Table S9, respectively.

Validation of the microarray upregulation results by qRT-PCR Quantitative reverse transcription PCR (q-RT-PCR) was used to validate the microarray results for 11 of the most overexpressed detoxification genes. These genes include six cytochrome P450s (CYP6M7, CYP4H17, CYP4C27, CYP6Z3, CYP9J11, CYP304b1), one dehydrogenase (Combined_c738), two glutathione transferases (GSTd3, GSTd1-5), one esterase (EstB1) and one aldehyde oxidase (Ald oxi). The qRT-PCR results confirmed significantly the overexpression of candidate genes at different levels. Same to the microarray results, the cytochrome P450 CYP6M7 was the most overexpressed detoxification gene (FC 11.69) in the R-S comparison (Fig. 3a). A significant correlation between the qRT-PCR and microarray results was observed $\left(R^{2}=0.358, P=0.046\right)$ (Fig. 3b).

\section{Role of knockdown resistance in lambda-cyhalothrin resistance}

PCR products were successfully amplified (994 bp) and sequenced for a fragment (a portion of intron 19 and the entire exon 20, domain II, segment 6) of the VGSC gene in ten field-collected $A n$. funestus female mosquitoes from Gankette Balla. An 868 bp common sequence was aligned for seven individuals detecting 15 polymorphic sites (Fig. 4). Neither the L1014F $k d r$ mutation nor the L1014S mutation was detected in An. funestus from Gankette Balla, as previously reported in other populations of this species [9, 11, 25]. Indeed, the VGSC gene sequencing analysis detected only the TTA 1014 codon indicating that they do not have the L1014F (TTA-to-TTT) or L1014S (TTA-to-TCA) kdr mutation (Additional file 10: Figure S1) commonly found in An. gambiae. 


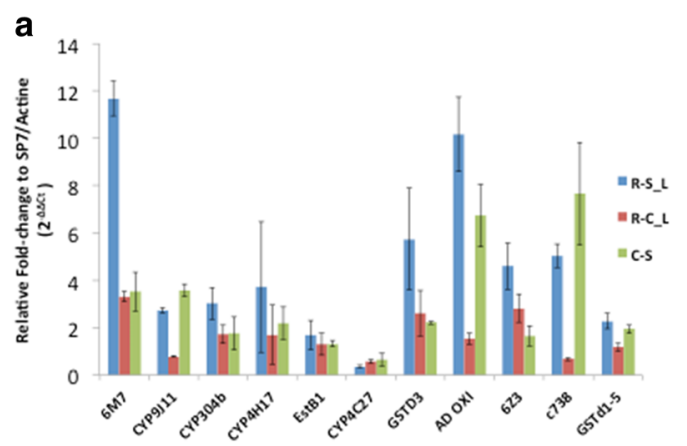

b

Fig. 3 Gene expression analysis. a q-RT PCR expression Profile of selected candidate genes in An. funestus resistant to lambda-cyhalothrin. b Correlation between the microarray and qRT-PCR fold change data for the selected candidates genes

\section{Discussion}

This study provides the first assessment of the susceptibility and mechanisms to the main insecticides used in public health of An. funestus population from Senegal.

\section{Susceptibility / resistance to lambda-cyhalothrin}

The results from this study show that An. funestus population from Gankette Balla is resistant to pyrethroids and DDT. In addition, suspected resistance was observed to bendiocarb and dieldrin. Resistance of An. funestus to different classes of insecticides has already been reported in West Africa [10, 11, 26], East Africa [9, 17] and in southern Africa [3, 4, 24, 27]. In Senegal, resistance to pyrethroids and DDT has already been reported in other

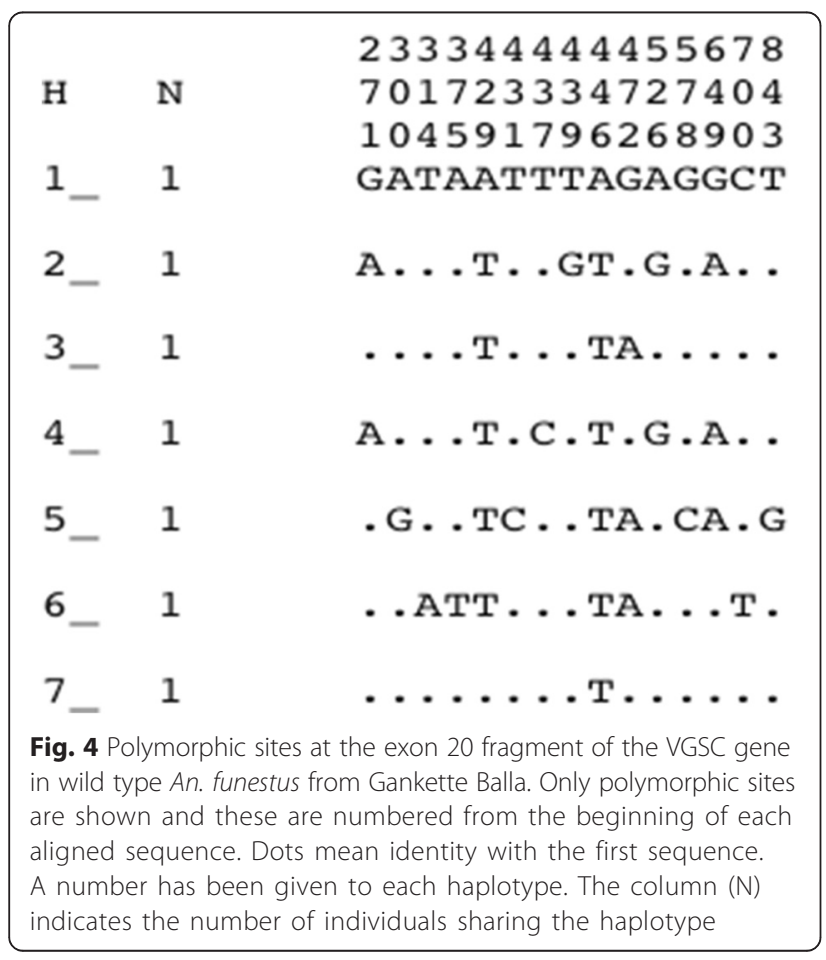

malaria vectors such as An. gambiae (s.l.) [12-14, 28] and $A n$. pharoensis [28].

On the other hand, our study revealed a resistance pattern where type II pyrethroid (lambda-cyhalothrin / deltamethrin) seems to be more involved compared to type I pyrethroids (permethrin). This resistance profile is different to that observed in An. funestus in Benin [11] where resistance is higher against type I pyrethroids. This difference could suggest the existence of a different resistance mechanism for pyrethroid resistance in Senegal compared to Benin. Indeed, some cytochrome P450s exhibit specificity for either or the two types of pyrethroids $[29,30]$. However, the observed resistance profile is similar to that reported in East Africa [17] and South Africa [31]. The full susceptibility observed for malathion is similar for all tests performed so far on An. funestus populations across Africa indicating that this insecticide could be used as an alternative to pyrethroids, carbamates and DDT in Indoor Residual Spraying (IRS) control program directed against this species [32].

The source of the lambda-cyhalothrin resistance observed in Gankette Balla remains unknown although the intense use of this insecticide in the agricultural sector could be a contributing factor. Indeed, due to the permanent availability of water around the Senegal River basin, yearly cultivation is well developed in Gankette Balla and pyrethroids are well represented in the pesticides used. This assumption is reinforced by the fact that the resistance of other malaria vectors to lambdacyhalothrin was observed in areas of high agricultural pressures in Senegal [28]. Moreover, the link between the resistance of $A n$. gambiae (s.l.) to insecticides and intensive use of pesticides has been already reported in areas where agriculture is highly developed [33-35].

In addition, another source of selection pressure could be likely linked to the use of type two pyrethroids insecticides (Deltamethrin) in treated bed nets in malaria vector control programs. In fact, the village of Gankette Balla was included during the scaling-up coverage with 
insecticide-treated nets against malaria in Senegal through the "Pal Fleuve" program in 2006.

Furthermore, the IRS campaign using the lambdacyhalothrin initiated a year later (2007) in the district of Richard Toll (lower valley of the Senegal River) could have been an additional contributing factor. Indeed, two years after this campaign, a lambda-cyhalothrin resistance in An. gambiae (s.l.) was observed in this area [28] and a link between this resistance and that observed in our study is not to exclude as previous studies have shown the existence of strong gene flow between populations of $A n$. funestus in the lower valley and that of the area of Lake Guiers [36]. The resistance of An. funestus to lambdacyhalothrin and deltamethrin may represent a potential threat to the success of the future vector control program directed against this major vector especially as pyrethroids are the only insecticide used for the impregnation of mosquito nets. This is a serious concern as other vectors of the study area are resistant to pyrethroids [28]. If such resistance is not managed properly, it can still be selected by the current vector control program (Insecticidetreated nets and IRS) to a level that will seriously affect the success of future programs against this major vector. A spread of the observed resistance in Gankette Balla is a concern for the continued effectiveness of pyrethroid-based interventions against $A n$. funestus in Senegal.

\section{Metabolic resistance mechanism is driving lambda-cyhalothrin resistance}

Analysis of the transcription profile of the Gankette Balla sample supported the importance of metabolic resistance mechanism in the observed pyrethroid resistance in this $A n$. funestus population as previously reported [32]. The importance of metabolic resistance mechanisms is shown through the consistent overexpression of genes involved in insecticide detoxification such as cytochrome P450 genes, GSTs, aldehyde oxidases and other gene families previously associated in resistance of $A n$. funestus to insecticides.

The P450 CYP6M7 was consistently the most overexpressed detoxification gene in lambda-cyhalothrin exposed mosquitoes compared to the FANG susceptible strain as well as to the unexposed mosquitoes. This gene was shown to be able to metabolise several pyrethroids including lambda-cyhalothrin [37], further supporting the likelihood that it could be the main resistance gene in this An. funestus population. A key role of such P450 gene will be in line with the common implication of the cytochrome P450 family genes in insecticide resistance as previously reported in several populations of $A n$. funestus [3, 37-39], An. gambiae (s.l.) [40], An. albimanus [41] and An. minimus [42]. This is also reported in several other insects [43-45]. More specifically, the role of cytochrome P450 in pyrethroid resistance has been reported in An. funestus from Benin [11], Ghana [10], Uganda [17], Mozambique [24, 27, 46, 47], Kenya [8] and Malawi [3], as well as in the laboratory resistant strain to permethrin $[38,48]$.

The overexpression of the CYP6M7 gene in lambdacyhalothrin resistant and non-exposed mosquitoes, compared to the susceptible strain suggests that it plays a key role in pyrethroid metabolic resistance in An. funestus in Gankette Balla similar to recent reports for the important role of this gene in Zambia [6,37]. Surprisingly, one of the duplicated P450 genes, CYP6P9a, which has been shown to play a main role in pyrethroid resistance in southern populations of An. funestus [3, 38, 39, 49] was not overexpressed at all. The complete absence of overexpression of CYP6P9a indicates that the resistance mechanism in Senegal is different to that observed in southern Africa. A similar difference is also observed for the GSTe2 gene which is not overexpressed at all in the Gankette Balla population whereas it was among the highest overexpressed in a DDT and pyrethroid resistant population from Benin, another West Africa country. It will be interesting to investigate the role of other GST genes overexpressed in the Gankette Balla population such as GSTd3 and GSTd1-5 to see what role they play in the observed DDT resistance.

Furthermore, the overexpression of several other genes from the microarray analysis suggests that in addition to CYP6M7, other genes may also play a role or involved in subsequent phases of pyrethroid detoxification. Further functional characterisation studies will help to establish these roles.

\section{Conclusions}

This study has provided the first assessment of the susceptibility to the main insecticides used in public health of an $A n$. funestus population from Senegal and also explored the possible mechanisms responsible for the pyrethroid resistance observed. The resistance profile observed in the Gankette Balla population highlights the need for further studies to assess the extent and the geographical distribution of these resistances in $A n$. funestus populations in Senegal as well as an assessment of its impact on malaria control programs. This will improve the implementation and management of future control programs against this important malaria vector in Senegal and in Africa in general.

\section{Additional files}

Additional file 1: Table S1. List of primers used in this study. (DOCX $72 \mathrm{~kb}$ ) Additional file 2: Table S2. Insecticide resistance profile of Anopheles funestus population from Senegal. (DOCX $54 \mathrm{~kb}$ ) 
Additional file 3: Table S3. Top 50 the most detoxification genes commonly overexpressed in the comparisons R-S_L and C-S (FC $\geq 2$, $P \leq 0.05)$. (DOCX $108 \mathrm{~kb})$

Additional file 4: Table S4. Top 50 the most detoxification genes overexpressed in the R-S_L comparisons ( $F C \geq 2, P \leq 0.05$ ). (DOCX $106 \mathrm{~kb}$ )

Additional file 5: Table S5. Top 50 the most detoxification genes overexpressed in the R-C_L comparisons ( $F C \geq 1.5, P \leq 0.05$ ). (DOCX $96 \mathrm{~kb}$ )

Additional file 6: Table S6. Detoxification genes commonly under expressed in the comparisons R-S_L, C-S (FC $\geq 2)$ and R-C_L (FC $\geq 1.5)$ $P \leq 0.05$. (DOCX $54 \mathrm{~kb}$ )

Additional file 7: Table S7. Top 50 the most detoxification genes commonly under expressed in the comparisons R-S_L and C-S (FC $\geq 2$, $P \leq 0.05)$. (DOCX $110 \mathrm{~kb}$ )

Additional file 8: Table S8. Top 50 the most detoxification genes under expressed in the R-S_L comparisons ( $F C \geq 2, P \leq 0.05$ ). (DOCX $100 \mathrm{~kb}$ )

Additional file 9: Table S9. Top 50 the most detoxification genes under expressed in the R-C_L comparisons ( $F C \geq 1.5, P \leq 0.05$ ). (DOCX $95 \mathrm{~kb}$ )

Additional file 10: Figure S1. Region flanking the kdr codon 1014 (TTA, indicated in red), showing no variation in wild type An. funestus from Gankette Balla. (TIF $1521 \mathrm{~kb}$ )

\section{Abbreviations}

CDNA, complementary deoxyribonucleic acid; CRNA, complementary ribonucleic acid; DDT, dichlorodiphenyltrichloroethane; DNA, deoxyribonucleic acid; FC, fold change; GABA, gamma-aminobutyric acid; GST, glutathione s-transferase; GSTd1-5, glutathione-s-transferase d1-5; GSTd3, glutathiones-transferase d3; GSTe2: glutathione-s-transferase epsilon 2; IRS, indoor residual spraying; Kdr, Knockdown resistance; LLINs, long-lasting insecticide nets; $P C R$, polymerase Chain Reaction; QPCR, real-time quantitative PCR; GRT-PCR, quantitative reverse transcriptase polymerase chain reaction; RNA, ribonucleic acid; RSP7, ribosomal protein S7; VGSC, voltage-gated sodium channel gene; WHO, World Health Organisation

\section{Acknowledgments}

This work was supported by the Malaria Capacity Development Consortium (MCDC) which is funded by the Wellcome Trust (Grant number WT084289MA) and the Bill \& Melinda Gates Foundation (Grant number: 51941). We are grateful to Khalifa Thiam, Moussa Fall and Youssou Coulibaly for technical assistance and help during field investigations and the villagers for their cooperation. The authors would like to thank Gareth Weedal for helpful comments and suggestions during sequences analysis.

\section{Funding}

This work was supported by the Malaria Capacity Development Consortium (MCDC). The funder had no role in study design, data collection or analysis, interpretation of data, decision to publish or preparation of the manuscript.

\section{Availability of data and materials}

The datasets supporting the conclusions of this article are included within the article and its additional files.

\section{Authors' contributions}

CSW, BS and OF designed the study. OF, ID, LK and CSW supervised the study. BS carried out the field collections and performed the experiments with assistance of H.I. JMR contributed toward data analysis. BS and CSW analysed the data and wrote the manuscript. All authors read, critically revised, read and approved the final manuscript.

\section{Competing interests}

The authors declare that they have no competing interests.

\section{Consent for publication}

Not applicable.

Ethics approval and consent to participate Not applicable.

\section{Author details}

'Laboratoire d'Écologie Vectorielle et Parasitaire, Département de Biologie Animale, Faculté des Sciences et Techniques, Université Cheikh Anta Diop de Dakar, Dakar-Fann, BP 5005, Sénégal. ²Department of Vector Biology, Liverpool School of Tropical Medicine, Pembroke Place, Liverpool L3 5QA, UK. ${ }^{3}$ Research Unit Liverpool School of Tropical Medicine, Organisation de Coordination pour la lutte contre les Endémies en Afrique Centrale, P.O Box 288, Yaoundé, Cameroon. ${ }^{4}$ Unité d'Entomologie Médicale, Institut Pasteur de Dakar, 36 Avenue Pasteur, BP 220 Dakar, Sénégal.

Received: 2 May 2016 Accepted: 28 July 2016

Published online: 12 August 2016

References

1. WHO. Global Malaria Program. Geneva: World malaria report; 2014.

2. PNLP: Rapport statistique 2010-2013. Programme National de Lutte contre le Paludisme (PNLP) Ministère de la Santé et de la Prévention Médicale. 2014. p. 33.

3. Riveron JM, Irving H, Ndula M, Barnes KG, Ibrahim SS, Paine MJ, Wondji CS. Directionally selected cytochrome P450 alleles are driving the spread of pyrethroid resistance in the major malaria vector Anopheles funestus. Proc Natl Acad Sci U S A. 2013;110(1):252-7.

4. Riveron JM, Yunta C, Ibrahim SS, Djouaka R, Irving H, Menze BD, Ismail HM, Hemingway J, Ranson H, Albert A, et al. A single mutation in the GSTe2 gene allows tracking of metabolically based insecticide resistance in a major malaria vector. Genome Biol. 2014;15(2):R27.

5. Choi KS, Christian R, Nardini L, Wood OR, Agubuzo E, Muleba M, Munyati S, Makuwaza A, Koekemoer LL, Brooke BD, et al. Insecticide resistance and role in malaria transmission of Anopheles funestus populations from Zambia and Zimbabwe. Parasit Vectors. 2014;7:464.

6. Thomsen EK, Strode C, Hemmings K, Hughes AJ, Chanda E, Musapa M, Kamuliwo M, Phiri FN, Muzia L, Chanda J, et al. Underpinning sustainable vector control through informed insecticide resistance management. PLoS One. 2014;9(6):e99822.

7. Wondji CS, Dabire RK, Tukur Z, Irving H, Djouaka R, Morgan JC. Identification and distribution of a GABA receptor mutation conferring dieldrin resistance in the malaria vector Anopheles funestus in Africa. Insect Biochem Mol Biol. 2011;41(7):484-91

8. Kawada H, Dida GO, Ohashi K, Komagata O, Kasai S, Tomita T, Sonye G, Maekawa Y, Mwatele C, Njenga SM, et al. Multimodal pyrethroid resistance in malaria vectors, Anopheles gambiae s.s., Anopheles arabiensis, and Anopheles funestus S.S. in western Kenya. PLoS One. 2011;6(8):e22574.

9. Mulamba C, Riveron JM, Ibrahim SS, Irving H, Barnes KG, Mukwaya LG, Birungi J, Wondji CS. Widespread pyrethroid and DDT resistance in the major malaria vector Anopheles funestus in East Africa is driven by metabolic resistance mechanisms. PLoS One. 2014;9(10):e110058.

10. Okoye PN, Brooke BD, Koekemoer LL, Hunt RH, Coetzee M. Characterisation of DDT, pyrethroid and carbamate resistance in Anopheles funestus from Obuasi, Ghana. Trans R Soc Trop Med Hyg. 2008;102(6):591-8.

11. Djouaka R, Irving H, Tukur Z, Wondji CS. Exploring mechanisms of multiple insecticide resistance in a population of the malaria vector Anopheles funestus in Benin. PLoS One. 2011;6(11):e27760.

12. Ndiath MO, Sougoufara S, Gaye A, Mazenot C, Konate L, Faye O, Sokhna C, Trape JF. Resistance to DDT and pyrethroids and increased kdr mutation frequency in An. gambiae after the implementation of permethrin-treated nets in Senegal. PLoS One. 2012;7(2):e31943

13. Ndiath MO, Cailleau A, Orlandi-Pradines E, Bessell P, Pages F, Trape JF, Rogier C. Emerging knock-down resistance in Anopheles arabiensis populations of Dakar, Senegal: first evidence of a high prevalence of kdr-e mutation in West African urban area. Malar J. 2015;14(1):364.

14. Niang el HA, Konate L, Diallo M, Faye O, Dia I. Patterns of insecticide resistance and knock down resistance $(k d r)$ in malaria vectors An. arabiensis, An. coluzzii and An. gambiae from sympatric areas in Senegal. Parasit Vectors. 2016;9(1):71.

15. Thwing Jl, Perry RT, Townes DA, Diouf MB, Ndiaye S, Thior M. Success of Senegal's first nationwide distribution of long-lasting insecticide-treated nets to children under five - contribution toward universal coverage. Malar J. 2011;10:86.

16. PNLP. Rapport d'activités 2012. Programme National de Lutte contre le Paludisme (PNLP) Ministère de la Santé et de la Prévention Médicale. 2013. 
17. Morgan JC, Irving H, Okedi LM, Steven A, Wondji CS. Pyrethroid resistance in an Anopheles funestus population from Uganda. PLoS One. 2010;5(7):e11872.

18. Gillies MT, Coetzee M. A Supplement to the Anophelinae of Africa South of the Sahara (Afrotropical region). Johannesburg: The South African Institute for Medical Research; 1987.

19. Livak KJ. Organization and mapping of a sequence on the Drosophila melanogaster $X$ and $Y$ chromosomes that is transcribed during spermatogenesis. Genetics. 1984;107(4):611-34.

20. Koekemoer LL, Kamau L, Hunt RH, Coetzee M. A cocktail polymerase chain reaction assay to identify members of the Anopheles funestus (Diptera: Culicidae) group. Am J Trop Med Hyg. 2002;66(6):804-11.

21. WHO. Test procedures for insecticide resistance monitoring in malaria vector mosquitoes. Geneva: World Health Organization; 2013.

22. Crawford JE, Guelbeogo WM, Sanou A, Traore A, Vernick KD, Sagnon N, Lazzaro BP. De novo transcriptome sequencing in Anopheles funestus using Illumina RNA-seq technology. PLoS One. 2010;5(12):e14202.

23. Schmittgen TD, Livak KJ. Analyzing real-time PCR data by the comparative C(T) method. Nat Protoc. 2008;3(6):1101-8

24. Cuamba N, Morgan JC, Irving H, Steven A, Wondji CS. High level of pyrethroid resistance in an Anopheles funestus population of the Chokwe District in Mozambique. PLoS One. 2010;5(6):e11010.

25. Riveron JM, Chiumia M, Menze BD, Barnes KG, Irving H, Ibrahim SS, Weedall GD, Mzilahowa T, Wondji CS. Rise of multiple insecticide resistance in Anopheles funestus in Malawi: a major concern for malaria vector control. Malar J. 2015;14:344

26. Coetzee $M$, van Wyk P, Booman M, Koekemoer LL, Hunt RH. Insecticide resistance in malaria vector mosquitoes in a gold mining town in Ghana and implications for malaria control. Bull Soc Pathol Exot. 2006;99(5):400-3.

27. Kloke RG, Nhamahanga E, Hunt RH, Coetzee M. Vectorial status and insecticide resistance of Anopheles funestus from a sugar estate in southern Mozambique. Parasit Vectors. 2011;4:16.

28. Faye O, Konate L, Diop A. Profil entomologique du paludisme au Sénégal. Ministère de la Santé et de la Prévention Médicale. 2011. p. 39.

29. Scollon EJ, Starr JM, Godin SJ, DeVito MJ, Hughes MF. In vitro metabolism of pyrethroid pesticides by rat and human hepatic microsomes and cytochrome p450 isoforms. Drug Metab Dispos. 2009;37(1):221-8.

30. Ibrahim SS, Riveron JM, Stott R, Irving H, Wondji CS. The cytochrome P450 CYP6P4 is responsible for the high pyrethroid resistance in knockdown resistance-free Anopheles arabiensis. Insect Biochem Mol Biol. 2016;68:23-32.

31. Hargreaves K. KLL, Brooke B.D., Hunt R.H., Mthembu J. and Coetzee M. Anopheles funestus resistant to pyrethroid insecticides in South Africa. Med Vet Entomol. 2000;14(2):181-9.

32. Coetzee M, Koekemoer LL. Molecular systematics and insecticide resistance in the major African malaria vector Anopheles funestus. Annu Rev Entomol. 2013;58:393-412

33. Diabate A, Baldet T, Chandre F, Akoobeto M, Guiguemde TR, Darriet F, Brengues C, Guillet P, Hemingway J, Small GJ, et al. The role of agricultural use of insecticides in resistance to pyrethroids in Anopheles gambiae s.l. in Burkina Faso. Am J Trop Med Hyg. 2002;67(6):617-22.

34. Djegbe I, Boussari O, Sidick A, Martin T, Ranson H, Chandre F, Akogbeto M, Corbel $\mathrm{V}$. Dynamics of insecticide resistance in malaria vectors in Benin: first evidence of the presence of L1014S kdr mutation in Anopheles gambiae from West Africa. Malar J. 2011:10:261.

35. Dabire RK, Namountougou M, Sawadogo SP, Yaro LB, Toe HK, Ouari A, Gouagna LC, Simard F, Chandre F, Baldet T, et al. Population dynamics of Anopheles gambiae s.l. in Bobo-Dioulasso city: bionomics, infection rate and susceptibility to insecticides. Parasit Vectors. 2012;5:127.

36. Samb B, Dia I, Konate L, Ayala D, Fontenille D, Cohuet A. Population genetic structure of the malaria vector Anopheles funestus, in a recently re-colonized area of the Senegal River basin and human-induced environmental changes. Parasit Vectors. 2012;5:188.

37. Riveron JM, Ibrahim SS, Chanda E, Mzilahowa T, Cuamba N, Irving H, Barnes KG, Ndula M, Wondji CS. The highly polymorphic CYP6M7 cytochrome P450 gene partners with the directionally selected CYP6P9a and CYP6P9b genes to expand the pyrethroid resistance front in the malaria vector Anopheles funestus in Africa. BMC Genomics. 2014:15:817.

38. Amenya DA, Naguran R, Lo TC, Ranson H, Spillings BL, Wood OR, Brooke BD, Coetzee M, Koekemoer LL. Over expression of a cytochrome P450 (CYP6P9) in a major African malaria vector, Anopheles funestus, resistant to pyrethroids. Insect Mol Biol. 2008;17(1):19-25.
39. Wondji CS, Irving H, Morgan J, Lobo NF, Collins FH, Hunt RH, Coetzee M, Hemingway J, Ranson $\mathrm{H}$. Two duplicated P450 genes are associated with pyrethroid resistance in Anopheles funestus, a major malaria vector. Genome Res. 2009:19(3):452-9.

40. Mitchell SN, Stevenson BJ, Müller P, Wilding CS, Egyir-Yawson A, Field SG, Hemingway J, Paine MJl, Ranson H, Donnelly MJ. Identification and validation of a gene causing cross-resistance between insecticide classes in Anopheles gambiae from Ghana. Proc Natl Acad Sci. 2012;109(16):6147-52.

41. Rongnoparut $\mathrm{P}$, Boonsuepsakul S, Chareonviriyaphap T, Thanomsing N. Cloning of cytochrome P450, CYP6P5, and CYP6AA2 from Anopheles minimus resistant to deltamethrin. J Vector Ecol. 2003:28(2):150-8.

42. Rodpradit P, Boonsuepsakul S, Chareonviriyaphap T, Bangs MJ, Rongnoparut $P$. Cytochrome P450 genes: molecular cloning and overexpression in a pyrethroid-resistant strain of Anopheles minimus mosquito. J Am Mosq Control Assoc. 2005:21(1):71-9.

43. Kasai S, Scott JG. Overexpression of Cytochrome P450 CYP6D1 Is Associated with Monooxygenase-Mediated Pyrethroid Resistance in House Flies from Georgia. Pestic Biochem Physiol. 2000;68(1):34-41.

44. Zhu F, Parthasarathy R, Bai H, Woithe K, Kaussmann M, Nauen R, Harrison DA, Palli SR. A brain-specific cytochrome P450 responsible for the majority of deltamethrin resistance in the QTC279 strain of Tribolium castaneum. Proc Natl Acad Sci U S A. 2010;107(19):8557-62.

45. Feyereisen R. Arthropod CYPomes illustrate the tempo and mode in P450 evolution. Biochim Biophys Acta. 2011;1814(1):19-28.

46. Brooke BD, Kloke G, Hunt RH, Koekemoer LL, Temu EA, Taylor ME, Small G, Hemingway J, Coetzee M. Bioassay and biochemical analyses of insecticide resistance in southern African Anopheles funestus (Diptera: Culicidae). Bull Entomol Res. 2001;91(4):265-72.

47. Casimiro SL, Hemingway J, Sharp BL, Coleman M. Monitoring the operational impact of insecticide usage for malaria control on Anopheles funestus from Mozambique. Malar J. 2007;6:142.

48. Hunt RH, Brooke BD, Pillay C, Koekemoer LL, Coetzee M. Laboratory selection for and characteristics of pyrethroid resistance in the malaria vector Anopheles funestus. Med Vet Entomol. 2005;19(3):271-5.

49. Christian RN, Matambo TS, Spillings BL, Brooke BD, Coetzee M, Koekemoer LL. Age-related pyrethroid resistance is not a function of P450 gene expression in the major African malaria vector, Anopheles funestus (Diptera: Culicidae). Genet Mol Res. 2011;10(4):3220-9.

\section{Submit your next manuscript to BioMed Central and we will help you at every step:}

- We accept pre-submission inquiries

- Our selector tool helps you to find the most relevant journal

- We provide round the clock customer support

- Convenient online submission

- Thorough peer review

- Inclusion in PubMed and all major indexing services

- Maximum visibility for your research

Submit your manuscript at www.biomedcentral.com/submit
Biomed Central 